\title{
Perilaku dan persepsi masyarakat terhadap terjadinya kebakaran gambut di Kabupaten Ogan Komering Ilir Provinsi Sumatera Selatan
}

\section{Behaviour and perception of community on peat fire in Ogan Komering Ilir District, South Sumatera Province}

Ati Dwi Nurhayati ${ }^{\mathrm{a}}$, Bambang Hero Saharjo ${ }^{\mathrm{b}}$, Leti Sundawati ${ }^{\mathrm{c}}$, Syartinilia $^{\mathrm{d}}$, Yeni Vetrita ${ }^{\mathrm{e}}$

\footnotetext{
${ }^{\text {a }}$ Program Studi Ilmu Pengelolaan Sumberdaya Alam dan Lingkungan, Sekolah Pascasarjana, Institut Pertanian Bogor, Kampus IPB Darmaga Bogor, 16680, Indonesia [+62 8111112206]

${ }^{\mathrm{b}}$ Departemen Silvikultur, Fakultas Kehutanan dan Lingkungan, Institut Pertanian Bogor, Kampus IPB Darmaga Bogor, 16680, Indonesia

${ }^{\mathrm{c}}$ Departemen Manajemen Hutan, Fakultas Kehutanan dan Lingkungan, Institut Pertanian Bogor, Kampus IPB Darmaga Bogor, 16680, Indonesia

${ }^{\mathrm{d}}$ Departemen Arsitektur Landskap, Fakultas Pertanian, Institut Pertanian Bogor, Kampus IPB Darmaga Bogor, 16680, Indonesia

${ }^{e}$ Pusat Pemanfaatan Penginderaan Jauh, LAPAN, Jakarta Timur, 13220, Indonesia
}

\section{Article Info:}

Received: 03 - 10 - 2020

Accepted: 16 - $11-2020$

Keywords:

Forest and peatland fires, human activity, peatland fire management

Corresponding Author: Ati Dwi Nurhayati Program Studi Ilmu Pengelolaan Sumberdaya Alam dan Lingkungan, Sekolah Pascasarjana, Institut Pertanian Bogor;

Tel. +628111112206

Email:

awinur@yahoo.com

\begin{abstract}
South Sumatera Province experienced the worst peat fires in 2015, where the larger area is located in Ogan Komering Ilir (OKI) District. Human activity is very important factor in causing forest and peatland fires, due to almost 100\% of forest and land fires are caused by humans. One of the purposes of this paper is to study the human activities that could trigger forest and peatland fires in OKI District. The results of this study are expected to produce information about the causes of fires and provide scientifically based information for policy makers to prevent forest and peatland fires in OKI District. This research was conducted in six villages in three sub-districts, Perigi and Riding Village in Pangkalan Lampam Sub-District; Ulak Depati and Jungkal Village in Pampangan Sub-District; and Pulu Beruang and Ujung Tanjung Village in Tulung Selapan Sub-District. This research method included field observations, interviews, and analyzing Terra/Aqua MODIS satellite imagery data to estimate the burned area. Based on the interview, it had been found that the main behavior of the community that triggers peat fires is sonor, land preparation for plantation, and fishing. Terra/Aqua MODIS image analysis reveals that the area burned in 2015 and 2019, mostly occurred in swamp shrub and open land cover. The knowledge and perceptions of the local community in OKI District on forest and peatland fire control are classified as moderate (56.7\% - 83.3\%). Community participation in outreach and training activities can increase knowledge and perceptions on forest and peatland fire control. Public knowledge has an essential correlation with people's perceptions. Positive public perceptions on efforts to control fires will increase their participation. Community participation at the site level will determine the success of controlling forest and land fires.
\end{abstract}

How to cite (CSE Style $8^{\text {th }}$ Edition):

Nurhayati AD, Saharjo BH, Sundawati L, Sundawati L, Syartinilia, Vetrita Y. 2020. Perilaku dan persepsi masyarakat terhadap terjadinya kebakaran gambut di Kabupaten Ogan Komering Ilir Provinsi Sumatera Selatan. JPSL 10(4): 568-583. http://dx.doi.org/10.29244/jps1.10.4.568-583. 


\section{PENDAHULUAN}

Ekosistem gambut memiliki peranan yang sangat penting bagi kehidupan manusia dan merupakan pengendali iklim global karena kemampuannya dalam menyerap dan menyimpan karbon yang sangat tinggi. Indonesia memiliki kawasan gambut seluas 14905575 ha yang tersebar di Sumatera (43.18\%) Kalimantan (32.06\%) dan Papua (24.76\%) (BBSDLP, 2011). Namun dalam beberapa dekade terakhir ekosistem gambut berada dalam ancaman. Lahan gambut di Indonesia telah dimanfaatkan untuk berbagai kepentingan seperti pertanian, kehutanan, perkebunan dan pembangunan pemukiman, hasilnya sekitar 6.66 juta hektar atau sekitar 44.6\% dari luasan total lahan gambut terdegradasi (Wahyunto et al., 2013). Aktivitas manusia telah mengakibatkan deforestasi dan degradasi hutan rawa gambut selama dua dekade terakhir ini yang berdampak pada peningkatan emisi karbon (Murdiyarso dan Lebel, 2007). Adanya pembukaan hutan dan lahan gambut, pembuatan saluran drainase dan pembalakan liar menyebabkan lahan gambut yang merupakan lahan basah menjadi kering sehingga rentan terbakar. Penyebab degradasi pada lahan gambut salah satunya adalah kebakaran hutan dan lahan gambut (Masganti et al., 2014). Kebakaran gambut merupakan kebakaran yang sangat berbahaya karena sulit dideteksi dan dikendalikan terutama pada musim kemarau. Kebakaran gambut ini tidak dipengaruhi angin, sehingga pola penjalarannya tidak menentu serta sukar untuk menentukan dimana kebakaran itu sesungguhnya terjadi (Saharjo et al., 2017).

Pada tahun 2015 Indonesia mengalami fenomena El Nino yang memicu kekeringan yang cukup panjang, sehingga menyebabkan beberapa wilayah menjadi rentan terbakar. Kebakaran hutan dan lahan pada tahun 2015 merupakan kebakaran yang terbesar dalam dekade terakhir ini, yang menghanguskan areal sekitar 2.6 juta ha. Provinsi Sumatera Selatan memiliki sebaran areal kebakaran hutan dan lahan tertinggi pada tahun 2015, dibandingkan provinsi lainnya yaitu mencapai 641964 ha (Endrawati, 2016). Luas areal yang terbakar di Provinsi Sumatera Selatan tahun 2015 pada lahan gambut adalah 293239 ha dari total lahan gambut terbakar (869 754 ha), dan pada tanah mineral adalah 348275 ha dari total kebakaran di tanah mineral (1 741 657) (Trinirmalaningrum et al., 2015). Kabupaten Ogan Komering Ilir (OKI) mengalami kebakaran hutan dan lahan terluas pada tahun 2015, sebesar 377333 ha dan sekitar 16 ribu hotspot (satellite-based thermal anomalies/fire locations) terdeteksi di Kabupaten OKI pada periode kebakaran tersebut (Nurlia et al., 2018). Pada tahun 2019 kebakaran yang cukup parah kembali melanda Indonesia dan termasuk kebakaran terbesar selama tiga tahun terakhir ini. Pada tahun ini Provinsi Sumatera Selatan terbakar paling parah dibandingkan dengan provinsi lainnya dengan total area terbakar 336798 ha (KLHK, 2020).

Penyebab kebakaran hutan dan lahan di Indonesia hampir 100\% disebabkan oleh manusia (Syaufina, 2008). Faktor kelalaian maupun kesengajaan dari manusia merupakan penyebab utama terjadinya kebakaran hutan dan lahan (Suratmo et al., 2003). Adanya penggunaan api di lahan gambut dapat menyebabkan terjadinya kebakaran gambut. Kegiatan pembukaan dan penyiapan lahan dengan pembakaran yang dilakukan oleh masyarakat maupun korporasi memperparah kerusakan terhadap gambut. Beberapa hasil penelitian menunjukkan bahwa pembukaan lahan dengan pembakaran hanya membutuhkan biaya sepertiga hingga seperempat dari biaya pembukaan lahan tanpa bakar. Pada dasarnya masyarakat terpaksa melakukan penyiapan lahan dengan pembakaran, karena tidak mempunyai dana dan tidak ada pilihan lain selain membakar (Saharjo, 2016).

Kebakaran hutan dan lahan gambut secara nyata menyebabkan terdegradasinya kondisi lingkungan seperti hilangnya sumber daya gambut dan hilangnya fungsi penyerapan karbon, serta berdampak pula pada aspek sosial ekonomi bagi masyarakat. Tidak hanya kerugian secara ekonomi, tetapi juga memengaruhi kesehatan manusia (Watts dan Kobziar, 2012; Gaveau et al., 2014). Kebakaran hutan dan lahan gambut telah menimbulkan kerugian dan kerusakan terhadap lingkungan yang lebih besar dibandingkan dengan tanah mineral. Pada tahun 2015 kabut asap telah menyebar hingga ke Malaysia, Singapura dan sebagian kecil Thailand (KLHK, 2015). Kabut asap yang melintas batas negara (Transboundary Haze Pollution) dapat memengaruhi hubungan bilateral dan regional antara Indonesia dengan negara-negara tetangga. Kerugian dari 
kebakaran hutan dan lahan pada tahun 2015 diprediksi mencapai sekitar Rp 221 Triliun (16.1 miliar dolar AS) (World Bank, 2016).

Berdasarkan penyebab terjadinya kebakaran dan dampak yang ditimbulkan, maka upaya pencegahan kebakaran hutan dan lahan gambut sangat penting untuk dilakukan dengan lebih difokuskan kepada faktor manusia. Aktivitas manusia yang dapat memicu terjadinya kebakaran perlu dikaji lagi secara lebih spesifik. Lokasi terjadinya kebakaran yang biasanya identik dengan kegiatan manusia perlu diverifikasi secara pasti. Penentuan fokus wilayah kebakaran dapat dilakukan melalui pengamatan informasi sebaran titik panas, untuk mempermudah dan mempercepat identifikasi area kebakaran (Endrawati, 2016). Melalui identifikasi area bekas terbakar maka dapat diperoleh informasi mengenai luasan kebakaran dan tipe tutupan lahan lokasi kebakaran. Hubungan antara aktivitas manusia dan lingkungannya merupakan faktor utama yang memengaruhi perubahan tutupan hutan dalam ekosistem lahan gambut tropis (Medrilzam et al., 2013). Informasi ini sangat penting dalam upaya pencegahan kebakaran selanjutnya yang tepat sasaran. Selain itu keterlibatan masyarakat dalam upaya pencegahan kebakaran hutan dan lahan gambut sangat diperlukan. Pada umumnya tindakan ataupun sikap seseorang pada situasi tertentu, sebagian besar dilandasi oleh persepsinya (Hudiyani et al., 2017). Interpretasi dan pengetahuan masyarakat mengenai pengelolaan lahan gambut dan kejadian kebakaran diduga akan mempengaruhi persepsi masyarakat terhadap upaya pengendalian kebakaran hutan dan lahan gambut.

Berdasarkan latar belakang dan permasalahan yang telah diuraikan di atas, maka penelitian ini bertujuan untuk: 1) Mengidentifikasi area bekas terbakar di lahan gambut; 2) Menganalisis perilaku masyarakat yang dapat memicu terjadinya kebakaran gambut; 3) Mengkaji persepsi dan tingkat pengetahuan masyarakat terhadap pengendalian kebakaran hutan dan lahan gambut, 4) Menganalisis hubungan tingkat pengetahuan dan persepsi masyarakat terhadap pengendalian kebakaran hutan dan lahan gambut. Penelitian ini hanya dibatasi pada kajian pada tingkat tapak (desa), berdasarkan kejadian kebakaran pada tahun 2015 dan 2019. Hasil penelitian ini diharapkan dapat menghasilkan informasi mengenai penyebab kebakaran hutan dan lahan gambut dan dapat memberikan pertimbangan kebijakan bagi pemerintah dalam upaya pencegahan kebakaran hutan dan lahan gambut di Kabupaten OKI.

\section{METODE}

\section{Lokasi dan Waktu Penelitian}

Penelitian ini dilakukan di enam desa pada tiga kecamatan di Kabupaten OKI Provinsi Sumatera Selatan yaitu Desa Perigi dan Desa Riding di Kecamatan Pangkalan Lampam; Desa Ulak Depati dan Desa Jungkal di Kecamatan Pampangan; dan Desa Pulu Beruang dan Desa Ujung Tanjung di Kecamatan Tulung Selapan. Pemilihan kecamatan untuk penelitian ini didasarkan pada luas gambut dan jumlah hotspot. Adapun pemilihan lokasi desa penelitian adalah berdasarkan Keputusan Direktur Pengendalian Kebakaran Hutan dan Lahan Nomor SK. 9/PKHL/PPI.4/2/2018 tentang Desa Rawan Kebakaran Hutan dan Lahan tahun 2018 pada 21 Provinsi di Indonesia. Selain itu juga didasarkan pada analisis hotspot dan kejadian kebakaran. Informasi dari tokoh masyarakat dan aksesibilitas juga menentukan lokasi penelitian. Penelitian ini dilakukan pada bulan Juni sampai Agustus 2019.

\section{Metode Pengumpulan Data}

Data yang digunakan dalam penelitian ini meliputi data primer dan sekunder. Data primer diperoleh dari survei/observasi ke lokasi penelitian melalui wawancara terstruktur dan wawancara mendalam kepada masyarakat desa penelitian. Melalui wawancara ini akan diperoleh informasi karakteristik responden seperti umur, mata pencaharian dan pendidikan. Penentuan contoh dilakukan dengan systematic random sampling, metode ini merupakan pengambilan contoh secara sistematis dengan interval (jarak) tertentu dari suatu kerangka contoh yang telah diurutkan (Sugiarto et al., 2001). Jumlah contoh yang diambil adalah 30 responden dari setiap desa lokasi penelitian, sehingga total responden untuk keenam desa penelitian adalah 180. Untuk 570 
melengkapi informasi yang diperoleh, dilakukan wawancara mendalam dengan informan kunci (key informan) pada setiap lokasi penelitian.

Data sekunder berupa data tutupan lahan, informasi spasial daerah terbakar (burned area), dan hotspot untuk kejadian kebakaran tahun 2015 dan 2019. Data tutupan lahan tahun 2015 dan 2018 diperoleh dari Kementerian Lingkungan Hidup dan Kehutanan. Kedua data tersebut dapat menggambarkan jenis tutupan lahan yang berasosiasi dengan jenis bahan bakar sebelum kejadian kebakaran. Sedangkan informasi spasial daerah terbakar diunduh dari situs resmi Pusat Pemanfaatan Penginderaan Jauh, Lembaga Penerbangan dan Antariksa Nasional (LAPAN) sebagai penyedia data penginderaan jauh nasional (https://spbn.pusfatja.lapan.go.id/maps/4001, diakses pada tanggal 9 Agustus 2020). Area terbakar dideteksi menggunakan metode perubahan nilai NBR (Normalized Burned Ratio) atau parameter dNBR (difference Normalized Burn Ratio) dari citra satelit Terra/Aqua MODIS (Moderate Resolution Imaging Spectroradiometer) pada periode sebelum dan sesudah terjadinya kebakaran. Kebakaran pada tahun 2015 dideteksi dari citra Terra/Aqua MODIS mulai bulan Juli hingga Desember, sedangkan untuk tahun 2019 bulan Januari hingga November. Data hotspot (MCD14, Terra/Aqua MODIS Collection 6) diunduh dari situs NASA (https://firms.modaps.eosdis.nasa.gov/download/)_dengan periode waktu mulai dari 1 Januari hingga 31 Desember untuk setiap tahunnya.

\section{Metode Analisis Data}

\section{Analisis Data Primer}

Analisis data penelitian dilakukan secara deskriptif dengan menarasikan semua fakta yang ditemukan di lokasi penelitian khususnya mengenai perilaku masyarakat yang dapat menimbulkan kebakaran hutan dan lahan gambut yang dikaitkan dengan luas area kebakarannya. Persepsi masyarakat terhadap upaya pengendalian kebakaran hutan dan lahan gambut diperoleh mealui wawancara menggunakan kuisioner dengan mengajukan 30 pernyataan positif mengenai pengelolaan lahan gambut yang berkelanjutan, dampak yang ditimbulkan dari kebakaran gambut dan partisipasi masyarakat dalam pengendalian kebakaran hutan dan lahan gambut. Tingkat persepsi responden diukur dengan menggunakan skala Likert. Skala likert yang dibuat adalah pernyataan positif yang menjadi indikasi persepsi yang baik dan sikap yang baik. Untuk penelitian ini tersedia 4 pilihan jawaban yaitu "sangat setuju, setuju, tidak setuju dan sangat tidak setuju". Pemberian skor untuk Skala Likert adalah skor 4 untuk jawaban sangat setuju, skor 3 jawaban setuju, skor 2 jawaban tidak setuju dan skor 1 jawaban sangat tidak setuju. Persepsi ini selanjutnya dikategorikan menjadi rendah, sedang dan tinggi, berdasarkan total skor yang diperoleh, sehingga persepsi masyarakat dikategorikan seperti pada Tabel 1.

Tabel 1 Kategori tingkat persepsi masyarakat

\begin{tabular}{ccc}
\hline No & Kategori & Skor \\
\hline 1 & Rendah & $30-60$ \\
2 & Sedang & $61-90$ \\
3 & Tinggi & $91-120$ \\
\hline
\end{tabular}

Informasi mengenai tingkat penguasaan ataupun pengetahuan masyarakat mengenai kejadian kebakaran, dampak dan upaya pengendalian kebakaran hutan dan lahan gambut, diperoleh melalui wawancara menggunakan kuisioner dengan mengajukan 20 pernyataan yang positif. Tingkat penguasaan pengetahuan masyarakat kemudian diukur dengan menggunakan Skala Likert (Hudiyani et al., 2017) dengan 4 pilihan penilaian yaitu buruk, kurang baik, cukup baik dan baik. Pemberian skor untuk Skala Likert adalah skor 4 untuk tingkat penguasaan baik, skor 3 apabila cukup baik, skor 2 kurang baik dan skor 1 apabila penguasaan materi buruk. Tingkat penguasaan mengenai pengetahuan ini selanjutnya dikategorikan menjadi rendah, sedang dan tinggi, berdasarkan total skor yang diperoleh dari seluruh pernyataan, sehingga tingkat pengetahuan masyarakat dikategorikan seperti pada Tabel 2. 
Tabel 2 Kategori tingkat pengetahuan masyarakat berdasarkan total skor seluruh pernyataan

\begin{tabular}{ccc}
\hline No & Kategori & Skor \\
\hline 1 & Rendah & $20-40$ \\
2 & Sedang & $41-60$ \\
3 & Tinggi & $61-80$ \\
\hline
\end{tabular}

Korelasi antara tingkat pengetahuan dan persepsi masyarakat diuji dengan uji korelasi Rank Spearman (Sugiyono, 2011) menggunakan SPSS 25.0 dengan rumus sebagai berikut :

$$
\begin{aligned}
& \rho=1-\frac{6 \Sigma d_{i}{ }^{2}}{n\left(n^{2}-1\right)} \\
& \rho=\text { Koefisien korelasi spearmen } \\
& d_{i}=\text { Selisih peringkat antara dua rangking } \\
& \text { pengamatan } \\
& n=\text { Banyaknya pasangan data }
\end{aligned}
$$

Uji signifikansi dilakukan untuk mengetahui hubungan yang signifikan antara variabel yang diuji. Hipotesisnya adalah sebagai berikut:

$\mathrm{H}_{\mathrm{o}}=$ Tidak ada hubungan antara tingkat pengetahuan dan persepsi masyarakat

$\mathrm{H}_{1}=$ Terdapat hubungan antara tingkat pengetahuan dan persepsi masyarakat

Jika nilai signifikansi $<0.05$ maka berkorelasi

Jika nilai signifikansi $>0.05$ maka tidak berkorelasi

Tingkat keeratan hubungan antara variabel dengan uji Rank Spearman disajikan pada Tabel 3.

Tabel 3 Tingkat hubungan antara variabel

\begin{tabular}{ccc}
\hline Interval & $\begin{array}{c}\text { Tingkat Hubungan } \\
\text { (Correlation Coeffisient) }\end{array}$ \\
\hline $0.00-0.25$ & Sangat lemah \\
$>0.26-0.50$ & Cukup \\
$>0.50-0.75$ & Kuat \\
$>0.75-1.00$ & Sangat kuat \\
\hline
\end{tabular}

Sumber : Sarwono (2006)

Kriteria arah hubungan dapat dilihat dari koefisien korelasi (correlation coeffisient). Nilai koefisien korelasi besarnya antara -1 sampai dengan +1 . Apabila nilai koefisien korelasi bernilai positif, maka hubungan kedua variabel searah. Demikian sebaliknya, apabila nilai koefisien korelasinya bernilai negatif maka hubungan kedua variabel tidak searah.

\section{Analisis Data Sekunder}

LAPAN menyediakan shapefile data hasil pemetaan daerah kebakaran untuk seluruh Indonesia sehingga dapat dengan mudah dianalisis lebih lanjut dengan menggunakan perangkat lunak Sistem Informasi Geografis. Untuk keperluan studi ini, data tersebut diekstrak hanya untuk wilayah gambut OKI. Demikian pula dengan jenis tutupan lahan dan hotspot pada tahun 2015 dan 2019 pada lokasi yang terdeteksi sebagai daerah terbakar dari data Terra/Aqua MODIS. Total daerah terbakar pada tiap desa/kecamatan dengan jenis tutupan lahannya dihitung untuk dianalisis lebih lanjut. Data hotspot di wilayah OKI selanjutnya dianalisis dengan melihat tren perubahan jumlahnya sejak awal hingga akhir kebakaran. Pada wilayah dimana pemetaan kebakaran berbasiskan data satelit tidak mampu mendeteksi, sebaran hotspot maka akan dilengkapi dengan laporan pemadaman kebakaran dari Kementerian Lingkungan Hidup dan Kehutanan (KLHK) yang digunakan untuk analisis secara deskriptif. 


\section{HASIL DAN PEMBAHASAN}

\section{Kebakaran Hutan dan Lahan Gambut di Kabupaten OKI}

\section{Analisis Sebaran Titik Panas}

Titik panas (hotspot) merupakan indikator kebakaran hutan yang mendeteksi suatu lokasi yang memiliki suhu yang relatif lebih tinggi dibandingkan dengan suhu sekitarnya (Peraturan Menteri Lingkungan Hidup dan Kehutanan Nomor P.32/MenLHK/Setjen/Kum.1/3/2016). Untuk mengetahui informasi sebaran dan kecenderungan naik/turunnya titik panas pada tahun tertentu, maka perlu untuk menganalisis titik panas setiap tahunnya. Berdasarkan hasil perhitungan akumulasi hotspot selama lima tahun terakhir (2015-2019), jumlah hotspot pada tahun 2015 menunjukkan angka tertinggi yaitu sebesar 16254 hotspot (Gambar 1). Adanya fenomena El Nino pada tahun 2015, menyebabkan kebakaran bertahan cukup lama pada masa periode tersebut.

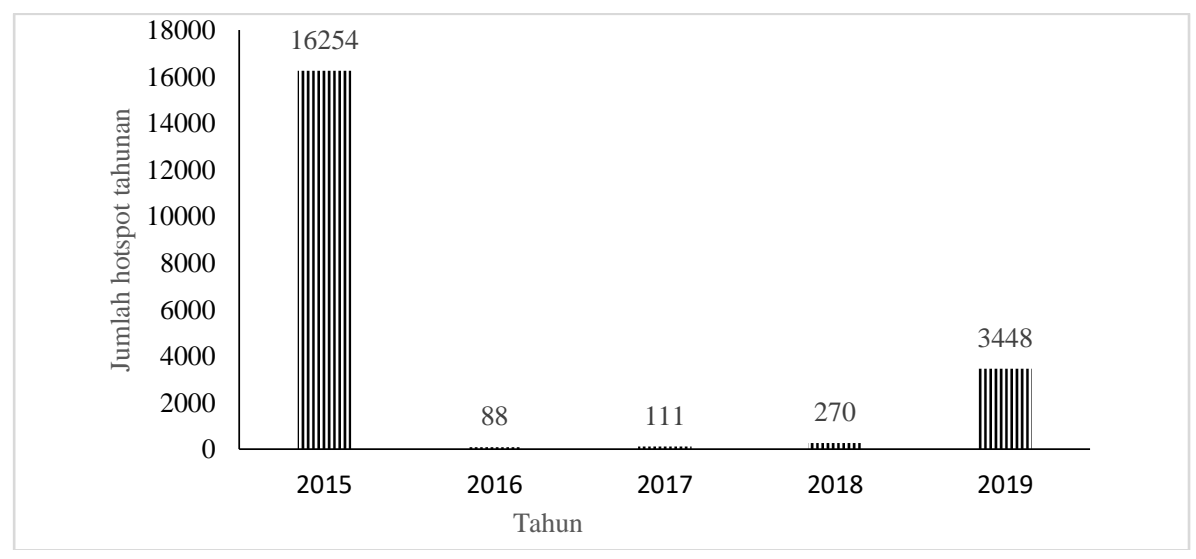

Gambar 1 Jumlah hotspot tahunan di Kabupaten OKI (Sumber: https://firms.modaps.eosdis.nasa.gov)

Pada tahun 2016 jumlah hotspot menurun tajam, menjadi 88 hotspot. Penurunan jumlah hotspot pada tahun 2016 selain disebabkan karena upaya yang dilakukan oleh pemerintah juga didukung dengan adanya fenomena La Nina. Berdasarkan prediksi ENSO oleh BMKG, pada tahun 2016 menunjukkan bahwa telah terjadi La Nina lemah. Jumlah hotspot mulai meningkat kembali pada tahun 2017 dan mencapai puncaknya pada tahun 2019 dengan jumlah 3448 hotspot. Hotspot dapat digunakan dalam mendeteksi dini kejadian kebakaran hutan dan lahan, namun hotspot tidak selalu berarti api/kebakaran. Dalam analisis hotspot yang perlu dipertimbangkan selain jumlah hotspot adalah confidence level. Sekitar 56.7\% hotspot di Kabupaten OKI memiliki confidence level $\geq 80 \%$, sehingga tingkat keyakinan kebakaran semakin tinggi (Endrawati et al., 2018).

\section{Identifikasi Area Bekas Terbakar di Lahan Gambut}

Pada studi ini area bekas kebakaran yang diidentifikasi hanya pada tahun 2015 dan 2019, dimana tahun 2015 merupakan kebakaran yang terluas pada enam tahun terakhir ini, sedangkan tahun 2019 merupakan kebakaran yang terluas pada tiga tahun terakhir ini. Total area terbakar pada tahun 2015 adalah sekitar 2611 411 ha dan total area kebakaran pada tahun 2019 adalah sekitar 1649258 ha (KLHK, 2020). Untuk mendukung kelengkapan informasi kejadian kebakaran hutan/lahan gambut tahun 2015 dan 2019 di lokasi penelitian, maka dilakukan identifikasi dan analisis area bekas kebakaran pada area studi. Area bekas terbakar (burned area) merupakan daerah yang menunjukkan ciri-ciri telah mengalami kejadian kebakaran. Berdasarkan pengamatan dan perhitungan luas kebakaran dengan menggunakan citra Terra/Aqua MODIS, luas area yang terbakar pada lahan gambut di Kabupaten OKI adalah 172760 ha pada tahun 2015 dan 22757 ha pada tahun 2019. Gambaran area bekas terbakar pada lahan gambut di Kabupaten OKI tahun 2015 dan 2019 disajikan pada Gambar 2. 


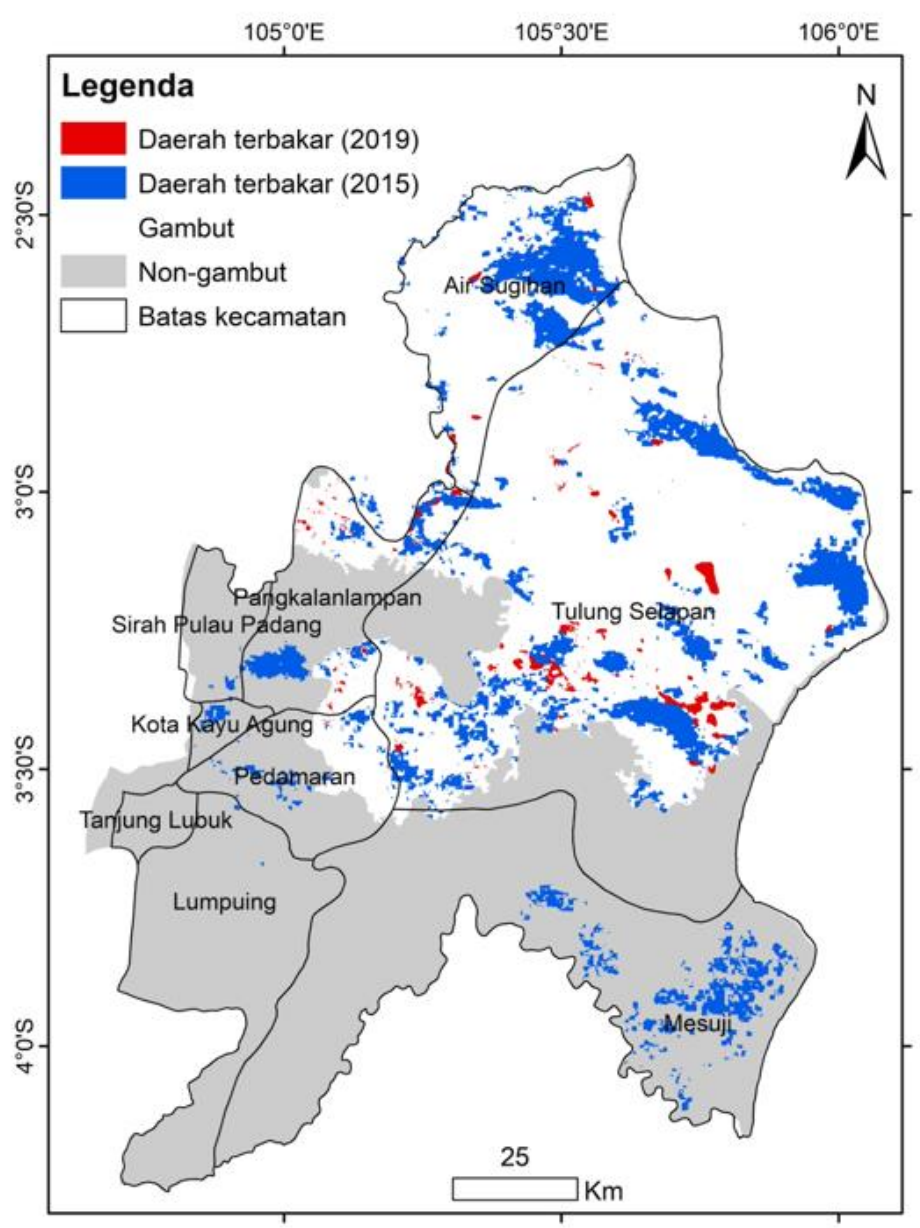

Gambar 2 Area terbakar di lahan gambut Kabupaten OKI pada tahun 2015 dan 2019

Berdasarkan hasil analisis area bekas terbakar, dapat diketahui bahwa wilayah Desa Riding mengalami kebakaran hebat pada tahun 2015 dan 2019, dengan total area terbakar sebesar 3795.1 ha (Tabel 4). Luas kebakaran ini menunjukkan angka yang paling tinggi dibandingkan dengan desa lainnya di wilayah studi. Wilayah Desa jungkal dan Desa Perigi juga terbakar cukup besar pada tahun 2015 dan tahun 2019, dengan total area terbakar 1105.3 ha (Desa Jungkal) dan 957.9 ha (Desa Perigi). Wilayah Desa Ujung Tanjung terbakar cukup luas pada tahun 2015 yaitu sebesar 1623.2 ha, namun tahun 2019 area yang terbakar pada desa ini tidak terdeteksi oleh citra Terra/Aqua MODIS. Demikian juga kebakaran yang terjadi di wilayah Desa Ulak Depati tahun 2015 dan 2019, serta kebakaran di Desa Pulu Beruang tahun 2019 tidak terdeteksi. Informasi lain mengenai area terbakar tahun 2019 di Desa Ujung Tanjung, diperoleh dari laporan pemadaman Daerah Operasional (DAOPS) Kabupaten OKI. Dalam laporannya diketahui bahwa total areal terbakar yang berhasil dipadamkan di Desa Ujung Tanjung pada tahun 2019 adalah seluas 22 ha yang tersebar pada berbagai tutupan lahan. Namun demikian tidak ada informasi mengenai luas kebakaran pada Desa Ulak Depati dan Desa Pulu Beruang. Berdasarkan hasil wawancara dengan responden, kedua desa ini mengalami kebakaran pada tahun 2015 dan 2019. Namun produk MODIS sama sekali tidak mendeteksi adanya kebakaran di wilayah tersebut.

Hal ini diduga karena keterbatasan ukuran kebakaran yang mampu diestimasi oleh MODIS menjadi faktor penyebabnya. Adapun citra MODIS memiliki kemampuan resolusi spasial sedang (500 meter), yang berasosiasi dengan kemampuan minimum area yang bisa terdeteksi. Dengan asumsi satu pixel berukuran 500 meter (6.25 ha), maka kebakaran yang mampu dideteksi pun paling tidak memiliki luas $>6.25$ ha. Meskipun demikian, salah satu produk global yang juga menggunakan MODIS sebagai input modelnya menyarankan penggunaan produk berbasis data ini untuk ukuran kebakaran $\geq 120$ ha (Giglio et al., 2003). 
Tabel 4 Luas area kebakaran di lahan gambut pada desa penelitian di Kabupaten OKI

\begin{tabular}{llccc}
\hline \multirow{2}{*}{ Kecamatan } & \multirow{2}{*}{ Desa } & \multicolumn{3}{c}{ Area Terbakar (Ha) } \\
\cline { 3 - 5 } & & Tahun 2015 & Tahun 2019 & Total \\
\hline \multirow{2}{*}{ Pampangan } & Jungkal & 828.3 & 277.0 & 1105.3 \\
& Ulak Depati & $*$ & $*$ & $*$ \\
\hline \multirow{2}{*}{ Tulung Selapan } & Pulu Beruang & $*$ & 158.0 & 158.0 \\
& Ujung tanjung & 1623.2 & $*$ & 1623.2 \\
\hline \multirow{2}{*}{ Pangkalan lampam } & Perigi & 459.8 & 498.1 & 957.9 \\
& Riding & 3052.3 & 742.8 & 3795.1 \\
\hline
\end{tabular}

Keterangan: Hasil olahan data citra Terra/Aqua MODIS LAPAN, (*): area terbakar tidak terdeteksi citra Terra/Aqua MODIS

Berdasarkan analisis area bekas terbakar dengan penutupan lahan, menunjukkan bahwa area kebakaran hutan/lahan lebih banyak terdapat di kelas penutupan lahan non hutan, yaitu di kelas belukar rawa. Luas area terbakar pada tutupan belukar rawa tahun 2015 yaitu seluas 2794.5 dan pada tahun 2019 sebesar 598.8 ha (Tabel 5). Tutupan lahan belukar rawa merupakan kawasan bekas hutan rawa yang telah tumbuh kembali atau kawasan dengan liputan pohon yang jarang (alami) atau kawasan dengan dominasi vegetasi rendah yang tumbuh secara alami (KLHK, 2019). Pada tutupan lahan belukar rawa memiliki keanekaragaman jenis yang sedikit atau rendah (Hastuti et al., 2014). Kondisi belukar rawa di lokasi penelitian saat ini, masih mengalami kerusakan akibat penebangan dan kebakaran. Kegiatan pembukaan hutan dan penyiapan lahan dengan pembakaran pada tahun 2015 masih masif dilakukan. Adanya pembukaan hutan dan pembuatan kanal menyebabkan bahan bakar di atas permukaan lebih mudah mengering dan terbakar terutama pada musim kemarau. Berbagai aktivitas masyarakat lainnya di Kabupaten OKI seperti berburu rusa dan konflik dengan perusahaan juga berpotensi menyebabkan belukar rawa ini terbakar.

Tabel 5 Luas area kebakaran gambut berdasarkan tutupan lahan pada desa penelitian di Kabupaten OKI

\begin{tabular}{lcc}
\hline \multicolumn{1}{c}{ Klasifikasi Tutupan dan } & \multicolumn{2}{c}{ Luas Area Terbakar (Ha) } \\
\cline { 2 - 3 } \multicolumn{1}{c}{ Penggunaan Lahan } & Tahun $2015^{\mathrm{a}}$ & Tahun $2019^{\mathrm{b}}$ \\
\hline Belukar rawa & 2794.5 & 598.8 \\
Tanah terbuka & 2236.9 & 728.1 \\
Hutan tanaman & 457.9 & 2.0 \\
Rawa & 238.2 & $*$ \\
Savana & 217.2 & 189.0 \\
Pemukiman & 19.0 & $*$ \\
Perkebunan & $*$ & 12.4 \\
\hline
\end{tabular}

Keterangan: ${ }^{\mathrm{a}}$ Menggunakan citra Terra/Aqua MODIS (data tutupan lahan) tahun 2015, ${ }^{\mathrm{b}}$ Menggunakan citra Terra/Aqua MODIS (data tutupan lahan) tahun 2018, *): data tidak tersedia

Selain pada tutupan belukar rawa, area bekas kebakaran juga ditemukan pada tanah terbuka dengan luasan yang cukup besar. Pada tahun 2015 luas area bekas kebakaran ditemukan pada tanah terbuka sebesar 2236.9 ha dan pada tahun 2019 seluas 728.1 ha. Tanah terbuka diduga merupakan hasil rekayasa manusia yang diusahakan atau dimanfaatkan untuk keperluan tertentu. Apabila dikaitkan dengan penyebab kebakaran yang telah diuraikan sebelumnya, berdasarkan wawancara dengan beberapa tokoh masyarakat diketahui bahwa kegagalan yang dialami dalam program cetak sawah, menjadikan kawasan tersebut menjadi lahan tidur. Kondisi lahan ini tidak dipergunakan lagi atau terlantar, dengan kondisi tersebut menyebabkan lahan ini ditutupi oleh tumbuhan yang tidak produktif seperti alang-alang dan semak belukar. Namun demikian pada akhirnya lahan tidur tersebut tetap dijadikan praktik sonor yang dalam persiapannya dilakukan pembakaran. 


\section{Karakteristik Mayarakat Desa di Kabupaten OKI}

Karakteristik masyarakat di Kabupaten OKI antara lain meliputi mata pencaharian, pendidikan formal dan pendidikan non formal. Pada Tabel 6 menunjukkan bahwa mayoritas responden (87\%-97\%) atau sekitar 164 responden dari total 180 responden di Kabupaten OKI memiliki mata pencaharian sebagai petani. Komoditas yang ditanam sebagian besar adalah padi dan karet. Namun ada juga yang menanam sayur-sayuran dan buah-buahan. Luasnya gambut yang tersebar di Kabupaten OKI menyebabkan masyarakat sebagian besar melakukan kegiatan pertanian, perkebunan maupun kehutanan di lahan gambut. Sebagian besar responden (40\%-67\%) atau sekitar 106 responden dari 180 responden pada lokasi penelitian menempuh pendidikan formal hanya sampai tingkat Sekolah Dasar (SD). Hal ini menunjukkan bahwa tingkat pendidikan formal di desa penelitian tergolong rendah, dimana berdasarkan Peraturan Pemerintah Republik Indonesia No. 47 Tahun 2008 tentang wajib belajar di Indonesia yaitu selama 9 tahun yaitu dari kelas 1 Sekolah Dasar (SD) hingga kelas 9 Sekolah Menengah Pertama (SMP).

Tabel 6 Karakteristik masyarakat desa di Kabupaten OKI

\begin{tabular}{|c|c|c|c|c|c|c|c|c|}
\hline \multirow[b]{2}{*}{ Karakteristik } & \multirow[b]{2}{*}{ Kategori } & \multicolumn{6}{|c|}{ Persentase (\%) } & \multirow[b]{2}{*}{$\begin{array}{c}\text { Total } \\
\text { Responden }\end{array}$} \\
\hline & & $\begin{array}{l}\text { Desa } \\
\text { Jungkal }\end{array}$ & $\begin{array}{l}\text { Desa } \\
\text { Ulak } \\
\text { Depati }\end{array}$ & $\begin{array}{c}\text { Desa } \\
\text { Pulu } \\
\text { Beruang }\end{array}$ & $\begin{array}{c}\text { Desa } \\
\text { Ujung } \\
\text { Tanjung }\end{array}$ & $\begin{array}{l}\text { Desa } \\
\text { Perigi }\end{array}$ & $\begin{array}{l}\text { Desa } \\
\text { Riding }\end{array}$ & \\
\hline \multirow{2}{*}{$\begin{array}{l}\text { Mata } \\
\text { Pencaharian }\end{array}$} & Petani & 87 & 87 & 90 & 97 & 97 & 90 & 164 \\
\hline & Bukan petani & 13 & 13 & 10 & 3 & 3 & 10 & 16 \\
\hline \multirow{3}{*}{$\begin{array}{l}\text { Pendidikan } \\
\text { formal }\end{array}$} & $\mathrm{SD}$ & 60 & 43 & 67 & 53 & 63 & 67 & 106 \\
\hline & SMP & 27 & 27 & 23 & 30 & 7 & 13 & 38 \\
\hline & SMA - PT & 13 & 30 & 10 & 17 & 30 & 20 & 36 \\
\hline \multirow[t]{3}{*}{$\begin{array}{l}\text { Pendidikan non } \\
\text { formal }\end{array}$} & $\begin{array}{l}\text { Tidak mengikuti } \\
\text { penyuluhan/pelatihan }\end{array}$ & 17 & 0 & 33 & 23 & 30 & 20 & 52 \\
\hline & $\begin{array}{l}\text { Mengikuti } \\
\text { penyuluhan/pelatihan }\end{array}$ & 60 & 70 & 57 & 57 & 47 & 70 & 85 \\
\hline & $\begin{array}{l}\text { Mengikuti } \\
\text { penyuluhan dan } \\
\text { pelatihan }\end{array}$ & 23 & 30 & 10 & 20 & 23 & 10 & 43 \\
\hline
\end{tabular}

Masyarakat cenderung lebih memilih untuk lebih cepat bekerja sebagai buruh tani, dalam memenuhi kebutuhan hidupnya dibandingkan menyelesaikan sekolahnya. Rendahnya tingkat pendidikan formal ini mengindikasikan bahwa masyarakat belum menyadari pentingnya pendidikan untuk kehidupannya. Hanya sebagian kecil saja yang berhasil menyelesaikan sekolahnya hingga jenjang yang lebih tinggi yaitu Sekolah Menengah Atas (SMA) dan Perguruan Tinggi. Pendidikan non formal yang dimaksud dalam studi ini berupa keikutsertaan dalam penyuluhan dan pelatihan mengenai pengendalian kebakaran hutan dan lahan gambut. Pendidikan non formal merupakan sarana penunjang dalam meningkatkan pengetahuan maupun wawasan masyarakat. Pada umumnya sebagian besar responden (47\%-70\%) di desa penelitian rata-rata telah mengikuti salah satu kegiatan saja yaitu penyuluhan atau pelatihan, dan hanya sekitar 10\%-30\% yang telah mengikuti kedua kegiatan tersebut. Kegiatan penyuluhan dan pelatihan yang dilakukan oleh pemerintah pusat maupun daerah bertujuan antara lain adalah untuk meningkatkan kesadaran masyarakat akan bahaya kebakaran hutan dan lahan gambut terhadap kesehatan dan lingkungan, serta meningkatkan keterampilan masyarakat dalam pemadaman kebakaran khususnya di lahan gambut. 


\section{Perilaku Masyarakat yang Dapat Memicu Terjadinya Kebakaran Gambut}

Luas lahan gambut di Provinsi Sumatera Selatan menurut Balai Besar Litbang Sumber Daya Lahan Pertanian (2011) adalah 1262384 ha. Kabupaten OKI memiliki gambut terluas di Provinsi Sumatera Selatan yakni sekitar 769000 ha (Wahyunto et al., 2005). Menurut Pemerintah Kabupaten OKI dalam Martin dan Winarno (2010) luas lahan rawa termasuk gambut dan danau di Kabupaten OKI mencapai sekitar 75\% dari total luas wilayahnya. Lahan gambut merupakan ekosistem lahan basah yang menjadi sumber mata pencaharian penting bagi masyarakat. Lahan basah menyediakan sumber daya yang dapat digunakan secara langsung, antara lain kayu kontruksi, bahan baku untuk anyaman tanaman herba untuk konsumsi dan obatobatan, ikan sebagai sumber protein (Chokkalingam et al., 2004). Tingginya aktivitas manusia di lahan gambut dapat menyebabkan ancaman bagi keberlanjutan ekosistem gambut. Penggunaan api seringkali digunakan dalam kegiatan pemanfaatan sumber daya tersebut, hal ini tentunya menyebabkan peluang terjadinya kebakaran gambut semakin tinggi. Berdasarkan hasil wawancara mendalam dengan para responden pada keenam desa penelitian, maka diperoleh informasi beberapa perilaku masyarakat yang dapat memicu terjadinya kebakaran di lahan gambut (Tabel 7). Informasi mengenai aktivitas masyarakat ini merupakan pengalaman yang pernah dialaminya terutama pada kejadian kebakaran sekitar tahun 2015 dan periode beberapa tahun sebelumnya. Pada semua desa lokasi penelitian, mayoritas responden mengatakan bahwa aktivitas masyarakat yang menjadi pemicu utama terjadinya kebakaran di lahan gambut adalah budidaya padi sonor, pembersihan lahan dengan pembakaran untuk kepentingan perkebunan maupun pertanian dan kegiatan mencari ikan.

Tabel 7 Perilaku masyarakat yang menyebabkan kebakaran hutan dan lahan gambut di Kabupaten OKI

\begin{tabular}{|c|c|c|c|c|c|c|}
\hline \multirow{2}{*}{ Aktivitas masyarakat } & \multicolumn{2}{|c|}{ Kec. Pampangan } & \multicolumn{2}{|c|}{ Kec. Tulung Selapan } & \multicolumn{2}{|c|}{$\begin{array}{l}\text { Kec. Pangkalan } \\
\text { Lampam }\end{array}$} \\
\hline & $\begin{array}{l}\text { Desa } \\
\text { Jungkal }\end{array}$ & $\begin{array}{c}\text { Desa } \\
\text { Ulak Depati }\end{array}$ & $\begin{array}{c}\text { Desa } \\
\text { Pulu Beruang }\end{array}$ & $\begin{array}{c}\text { Desa } \\
\text { Ujung Tanjung }\end{array}$ & $\begin{array}{c}\text { Desa } \\
\text { Riding }\end{array}$ & $\begin{array}{c}\text { Desa } \\
\text { Perigi }\end{array}$ \\
\hline Sonor & $\sqrt{ }$ & $\sqrt{ }$ & $\sqrt{ }$ & $\sqrt{ }$ & $\sqrt{ }$ & $\sqrt{ }$ \\
\hline $\begin{array}{l}\text { Pembersihan lahan } \\
\text { dengan pembakaran }\end{array}$ & $\sqrt{ }$ & $\sqrt{ }$ & $\sqrt{ }$ & $\sqrt{ }$ & $\sqrt{ }$ & $\sqrt{ }$ \\
\hline Mencari ikan & $\sqrt{ }$ & $\sqrt{ }$ & $\sqrt{ }$ & $\sqrt{ }$ & $\sqrt{ }$ & $\sqrt{ }$ \\
\hline $\begin{array}{l}\text { Konflik dengan } \\
\text { perusahaan }\end{array}$ & $\sqrt{ }$ & $*$ & $\sqrt{ }$ & $\sqrt{ }$ & $\sqrt{ }$ & $\sqrt{ }$ \\
\hline Perburuan rusa & $\sqrt{ }$ & $*$ & $*$ & $*$ & $\sqrt{ }$ & $*$ \\
\hline $\begin{array}{l}\text { Konflik antara pencari } \\
\text { kayu gelam }\end{array}$ & $*$ & $*$ & $*$ & $*$ & $\sqrt{ }$ & $*$ \\
\hline Membakar sampah & $*$ & $\sqrt{ }$ & $*$ & $\sqrt{ }$ & $*$ & $*$ \\
\hline $\begin{array}{l}\text { Membuang puntung } \\
\text { rokok }\end{array}$ & $*$ & $*$ & $\sqrt{ }$ & $*$ & $\sqrt{ }$ & $*$ \\
\hline
\end{tabular}

Keterangan: $\sqrt{ }$ : Perilaku yang menyebabkan kebakaran, $*)$ : tidak ada informasi

Luasnya lahan gambut di Kabupaten OKI memberikan peluang kepada masyarakat yang sebagian besar petani untuk bertanam padi. Permasalahan yang dihadapi dengan luasnya lahan garapan ini adalah keterbatasan tenaga kerja dan biaya, dalam mengatasi hal ini maka petani melakukan sonor. Penanaman padi dengan sistem sonor telah lama dilakukan oleh masyarakat lokal di Sumatera Selatan (Ratmini dan Yohanes, 2013). Sonor merupakan sistem penanaman padi di lahan rawa gambut, dimana dalam persiapan lahannya dilakukan dengan cara membakar semak/rumput di atas permukaan lahan gambut. Pada umumnya sonor ini dilakukan di lahan tidur dan pada musim kemarau yang berkepanjangan. Kegiatan persiapan lahan sampai dengan pembakaran biasanya dilakukan pada bulan Juli sampai dengan bulan Oktober. Benih padi disebarkan pada bulan November, kemudian ditinggalkan dan kembali lagi setelah kurang lebih enam bulan untuk panen padi. Petani 
berkeyakinan bahwa untuk menghasilkan panen padi yang maksimal, maka gambut harus dibakar. Petani mengungkapkan bahwa fakta yang terjadi sesungguhnya adalah produksi padi lebih baik hasilnya bila penyiapan lahannya dilakukan dengan pembakaran. Namun apabila tanpa bakar maka pertumbuhan padi hanya sekitar $20 \mathrm{~cm}$ saja dengan kualitas yang kurang baik. Sementara itu menurunnya harga karet sejak tahun 2014 sampai 2016, menyebabkan petani penggarap tidak ada pilihan lain selain melakukan sonor (Larastiti, 2018). Bertanam padi dengan sonor semata-mata dilakukan untuk mencukupi kebutuhan pangannya. Namun hal ini menjadi dilematis, dengan semakin masifnya kejadian kebakaran hutan dan lahan gambut pada tahun 2015 . Akibat kebakaran hutan dan lahan tahun 2015, pada tahun 2016 pemerintah mengambil langkah tegas dalam menegakkan peraturan mengenai larangan pembakaran hutan dan lahan oleh siapapun untuk alasan apapun. Hal ini menyebabkan para petani berpikir ulang dalam melakukan penyiapan lahan dengan pembakaran. Dalam situasi sulit seperti ini, Pemerintah Kabupaten OKI mengusulkan proyek cetak sawah sebagai strategi mengatasi harga karet yang tidak baik sekaligus menanggulangi kebakaran hutan dan lahan dan memberi target 11000 ha pembukaan sawah baru pada tahun 2016 (Larastiti, 2018). Namun demikian proyek cetak sawah ini mengalami kegagalan di hampir semua lokasi penelitian. Pada tahun 2016 lahan peruntukan cetak sawah seluas 860 ha di Desa Perigi mengalami kegagalan. Pada tahun 2017 proyek cetak sawah di Desa Jungkal pun tidak berhasil, sekitar $70 \%$ dari luasan 390 ha mengalami gagal panen. Pada akhirnya areal lahan yang diperuntukkan untuk cetak sawah pun dijadikan sebagai praktik sonor.

Penggunaan api dalam kegiatan penyiapan lahan tidak hanya untuk penanaman padi di gambut saja, tetapi juga untuk keperluan perkebunan dan pertanian. Pada area studi di tahun 2015, penyiapan lahan dengan pembakaran masih dilakukan untuk kemudian ditanami sayuran dan buah-buahan. Sistem pembakaran yang digunakan adalah dengan sistem rumpukan seluas 2 ha. Umumnya kegiatan penyiapan lahan diawali dengan penebasan vegetasi baik semak maupun pepohonan yang ada di atas permukaan lahan gambut. Pada tutupan lahan hutan, biasanya dilakukan penebangan pohon terlebih dahulu dan kayunya dikeluarkan untuk dimanfaatkan. Penebasan biasanya dilakukan selama 2 minggu dan bahan bakar di atas permukaan dikeringkan selama kurang lebih 2 bulan. Pembakaran biasanya dilakukan pada bulan Agustus, dan lamanya proses pembakaran hanya sekitar 2 jam untuk luasan 1 ha. Biasanya selama proses pembakaran lahan dijaga oleh kelompoknya yang beranggota sekitar 10 sampai dengan 25 orang. Terdapat peraturan adat yang telah diterapkan dalam kegiatan pembakaran ini, yaitu apabila terjadi perembetan api ke lahan tetangganya maka harus membayar sanksi berupa denda sejumlah pohon yang terbakar. Denda yang harus dibayarkan adalah sekitar Rp 100 hingga 200 ribu per pohon. Namun demikian pada tahun 2018 kegiatan pembakaran dalam penyiapan lahan untuk sonor maupun untuk pertanian/perkebunan di wilayah studi sudah semakin berkurang. Pengawasan terhadap kegiatan pembakaran diperketat terutama pada saat menjelang ASIAN Games di Kota Palembang tahun 2018 yang mengharuskan zero burning. Adanya pengawasan yang ketat pada saat itu menyebabkan ketakutan akan sanksi yang akan diberikan apabila membakar. Hal ini mendorong petani untuk mencari alternatif cara pengolahan lahan selain membakar. Namun pada kenyataannya pengelolaan tanpa bakar masih menimbulkan masalah bagi petani hal ini antara lain dikarenakan biaya yang lebih mahal, waktu tunggu yang lebih lama untuk lahan ditanam dan masalah hama. Mereka berpendapat belum ada teknologi yang lebih mudah, murah dan cepat selain pembakaran.

Hal lain yang dapat memicu terjadinya kebakaran di lahan gambut adalah mencari ikan. Aktivitas mencari ikan biasanya dilakukan pada musim kemarau sekitar bulan juli hingga september. Pada musim kemarau genangan air pada kawasan rawa mulai mengering dan ikan-ikan biasanya berkumpul pada kolam yang masih tergenang air yang biasanya disebut lebak lebung. Api digunakan untuk membersihkan vegetasi permukaan yang menutupi lebak lebung tersebut. Pada musim kemarau kondisi vegetasi permukaan menjadi lebih kering, sehingga akan mudah menyala apabila dibakar. Pada beberapa konsesi yang berdekatan dengan desa, masyarakat dilarang mencari ikan di wilayahnya bila memasuki musim kemarau. Konflik antara masyarakat desa dengan perusahaan seringkali terjadi. Permasalahan yang timbul seperti adanya tumpang tindih kepemilikan lahan antara lahan desa dan lahan perusahaan, pada akhirnya bisa berujung dengan penggunaan api. Kejadian kebakaran dengan motif seperti ini seringkali ditemukan di perbatasan antara perusahaan dan 578 
lahan masyarakat. Namun demikian tidak sedikit yang menduga bahwa kebakaran yang terjadi di wilayah desa, merupakan perembetan api yang berasal dari perusahaan.

Di Desa Jungkal dan Desa Riding, kegiatan berburu rusa dapat berpotensi menimbulkan terjadinya kebakaran. Api digunakan untuk membakar vegetasi permukaan saat berburu, untuk memancing rusa keluar dari tempat persembunyiannya sehingga akan lebih mudah untuk ditangkap. Namun demikian apabila pembakaran tidak terkontrol, maka api dapat menyebar dan menimbulkan kebakaran di lahan gambut. Konflik antara pencari gelam di Desa Riding dapat memicu terjadinya kebakaran. Permasalahan mengenai perselisihan lahan tempat pencari kayu gelam juga dapat memicu terjadinya konflik/persaingan antara sesama pencari gelam. Kayu gelam biasanya dimanfaatkan untuk kayu konstruksi, kayu bakar dan kayu gergajian. Pada kenyataannya gelam alam secara ekonomi dapat meningkatkan pendapatan yang cukup besar terhadap setiap pelaku yang terlibat, dimana besarannya tentunya akan berbeda pada setiap pelaku (Syachroni et al., 2019). Pencari gelam yang mendapatkan bagian lahan dengan jumlah gelam yang banyak, telah menimbulkan kecemburuan sosial bagi pencari gelam yang mendapat bagian lahan dengan jumlah gelam yang lebih sedikit. Kecemburuan ini menyebabkan pencari gelam yang kurang beruntung membakar lahan yang mempunyai kayu gelam yang lebih banyak. Berdasarkan informasi dari masyarakat, perilaku lain yang berpotensi dapat menyebabkan terjadinya kebakaran di lahan gambut adalah puntung rokok dan membakar sampah. Membakar sampah yang dilakukan di dekat kebun dan kemudian ditinggalkan dikategorikan sebagai perilaku kelalaian. Adanya angin dapat membantu penyebaran api ke kebun dan menyebabkan kebakaran di lahan gambut. Adapun perilaku membuang puntung rokok seringkali dinyatakan sebagai penyebab kebakaran hutan dan lahan. Namun beberapa penelitian di perguruan tinggi membuktikan bahwa puntung rokok tidak dapat menyebabkan terjadinya kebakaran (Syaufina, 2008).

\section{Pengetahuan dan Persepsi Masyarakat}

Persepsi merupakan proses pemberian makna, stimuli dan sensasi yang diterima oleh individu dan sangat dipengaruhi oleh faktor internal dan faktor eksternal dari masing-masing individu (Arifin et al., 2017). Faktor internal yang mempengaruhi persepsi seseorang antara lain adalah minat, motivasi dan karakteristik individu. Adapun faktor eksternal yang mempengaruhi antara lain adalah informasi yang diperoleh dan pengetahuan (Thoha, 2003). Terkait dengan penelitian ini, tingkat pengetahuan seseorang mengenai kebakaran hutan dan lahan gambut perlu untuk dianalisis, sebagai salah satu dasar dalam menentukan upaya pencegahan kebakaran selanjutnya.

Pada Gambar 3 dapat dilihat bahwa mayoritas tingkat pengetahuan masyarakat (56.7\%-80\%) mengenai kebakaran hutan dan lahan gambut termasuk dalam kategori sedang, namun masih ada yang termasuk dalam kategori rendah yaitu sekitar 20\%-60\%. Hal ini menunjukkan bahwa rata-rata masyarakat sudah memiliki pemahaman yang cukup baik. Namun pada kenyataannya masih terdapat masyarakat yang pemahamannya kurang baik, sehingga perlu ditingkatkan lagi pengetahuannya. Beberapa pernyataan yang disampaikan untuk mengukur tingkat pengetahuan responden adalah pertanyaan mengenai penyebab kebakaran hutan dan lahan gambut, dampak dan upaya pengendaliannya.

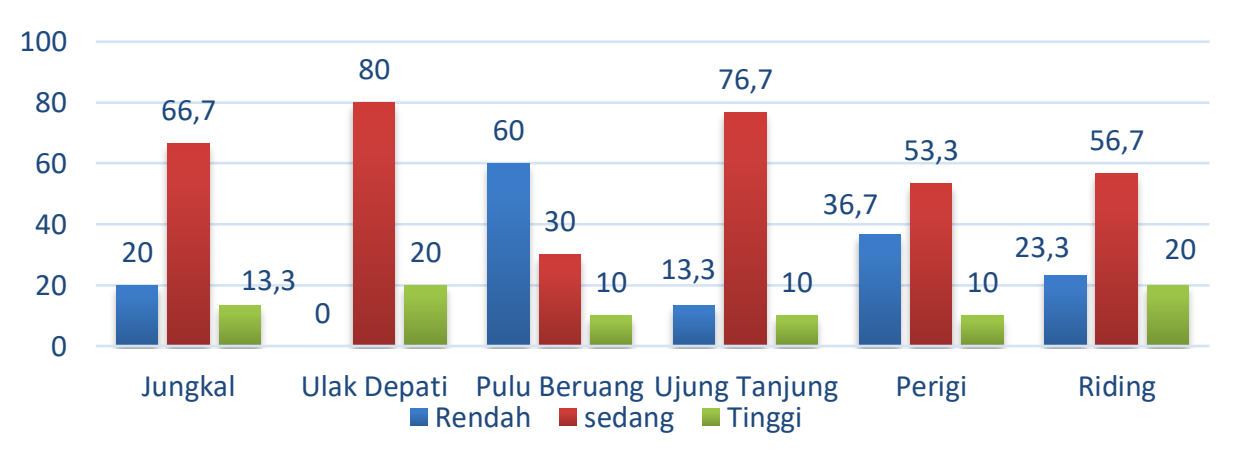

Gambar 3 Distribusi tingkat pengetahuan masyarakat terhadap kebakaran 
Pada Gambar 4 terlihat bahwa persepsi masyarakat (56.7\%-83.3\%) secara keseluruhan di lokasi penelitian berada pada kategori sedang terhadap pengendalian kebakaran hutan dan lahan gambut. Persepsi masyarakat di Desa Ulak Depati, Desa Ujung Tanjung dan Desa Riding berada pada kategori tinggi dan kategori sedang, serta tidak ada yang berada pada persepsi dengan kategori rendah. Mayoritas persepsi masyarakat yang sedang, menunjukkan bahwa masyarakat desa ini sudah memiliki persepsi yang baik terhadap pengendalian kebakaran hutan dan lahan gambut.

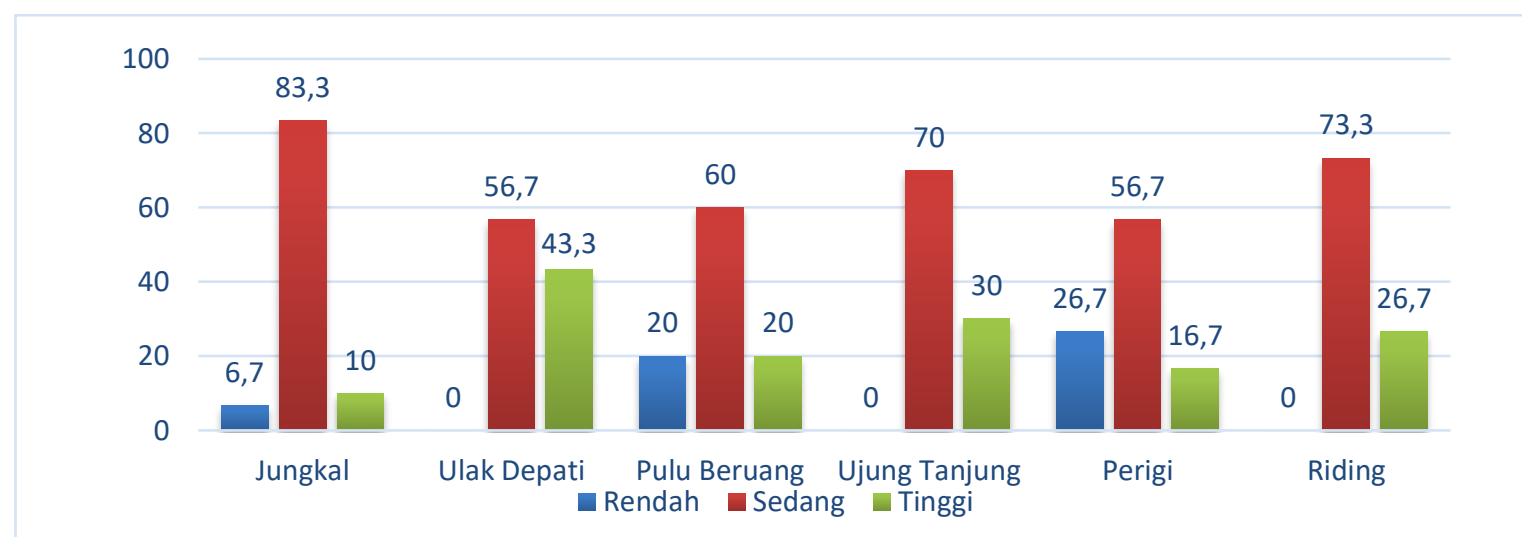

Gambar 4 Distribusi persepsi masyarakat terhadap upaya pengendalian kebakaran gambut di Kabupaten OKI

Pada Tabel 8 terlihat bahwa di seluruh wilayah studi nilai sig (2-tailed) $<0.05$ atau tolak H0, dengan nilainya yang berkisar antara 0.000 hingga 0.01 . Hal ini berarti bahwa terdapat korelasi/hubungan antara tingkat pengetahuan dan persepsi masyarakat terhadap pengendalian kebakaran hutan dan lahan gambut. Koefisien korelasi Rank Spearman antara pengetahuan dan persepsi masyarakat di seluruh wilayah studi adalah berkisar antara 0.400 hingga 0.809 . Korelasi yang positif antara dua variabel tersebut menunjukkan hubungan yang searah, yang berarti bahwa semakin tinggi wawasan dan pengetahuan masyarakat maka akan meningkatkan persepsi yang positif terhadap upaya pengendalian kebakaran hutan dan lahan gambut. Nilai korelasi ini menunjukkan hubungan yang cukup kuat hingga sangat kuat. Hal ini dibuktikan bahwa pengetahuan masyarakat yang diperoleh melalui keiikutsertaannya pada kegiatan penyuluhan maupun pelatihan mampu mempengaruhi persepsi masyarakat.

Tabel 8 Nilai koefisien hubungan antara tingkat pengetahuan dan persepsi masyarakat tentang pengendalian kebakaran hutan dan lahan gambut di Kabupaten OKI

\begin{tabular}{llll}
\hline \multicolumn{1}{c}{ Desa } & \multicolumn{1}{c}{$\begin{array}{c}\text { Nilai Signifikansi } \\
(\text { sig.(2-tailed) })\end{array}$} & Koefisien Korelasi & Kekuatan Hubungan \\
\hline Jungkal & 0.01 & $0.578^{* *}$ & Kuat \\
Ulak Depati & 0.002 & $0.535^{* *}$ & Kuat \\
Pulu Beruang & 0.028 & $0.400^{* *}$ & Cukup \\
Ujung Tanjung & 0.004 & $0.510^{* *}$ & Kuat \\
Perigi & 0.000 & $0.809^{* *}$ & Sangat kuat \\
Riding & 0.009 & $0.470^{* *}$ & Cukup \\
\hline
\end{tabular}

** Korelasi signifikan pada taraf nyata 0,01 (2-tailed)

Persepsi masyarakat di Kabupaten OKI yang sudah tergolong cukup baik, menyebabkan sebagian besar masyarakat sudah mulai ikut berpartisipasi dalam kegiatan pencegahan kebakaran hutan dan lahan gambut. Setelah peristiwa kebakaran tahun 2015 yang cukup parah, masyarakat mulai membentuk beberapa organisasi yang menunjukkan kepeduliannya terhadap kejadian kebakaran hutan dan lahan gambut. Bentuk partisipasi 
masyarakat antara lain adalah secara sukarela menjadi anggota pada beberapa organisasi yang dibentuk seperti Masyarakat Peduli Api (MPA), Kelompok Masyarakat Gambut Peduli Kebakaran (KMGPK) dan Desa Tangguh Bencana (Destana). Selain itu bentuk kepedulian masyarakat terhadap pencegahan kebakaran hutan/lahan, dimana pada saat menjelang musim kemarau masyarakat membuat embung air, melakukan patroli dan mendirikan pos-pos penjagaan di sekitar wilayah desanya. Beberapa desa seperti desa Ulak Depati sudah terlibat dalam kegiatan patroli terpadu yang dilakukan oleh Manggala Agni sejak tahun 2019. Patroli ini merupakan patroli gabungan antara Manggala Agni, MPA, BPBD, TNI dan petugas kepolisian yang beranggotan 7 orang. Upaya pencegahan kebakaran hutan dan lahan gambut yang sudah mulai rutin dilakukan di wilayah studi adalah sosialisasi dan penyuluhan serta himbauan mengenai kebakaran hutan dan lahan gambut, yang dilakukan oleh BRG, BPBD, Manggala Agni maupun aparat desa. Namun demikian kekurangan dalam pengendalian kebakaran hutan dan lahan gambut di tingkat desa ini adalah sarana dan prasarana yang kurang memadai untuk kegiatan pemadaman kebakaran. Minimnya peralatan pemadaman ini menyebabkan kebakaran tidak bisa ditangani dengan cepat. Pada beberapa kejadian kebakaran yang jaraknya jauh dari akses jalan, api dibiarkan menjalar sampai mendekati tepi jalan sehingga terjangkau oleh masyarakat untuk memadamkannya. Hal ini menyebabkan kebakaran menjadi semakin meluas. Dengan demikian partisipasi masyarakat yang cepat tanggap dan peralatan yang memadai sangat penting dalam memadamkan kebakaran, sehingga dapat mengurangi area yang terbakar. Sinergi yang baik antara masyarakat dan pemerintah daerah akan menentukan keberhasilan upaya pengendalian kebakaran hutan dan lahan.

\section{SIMPULAN}

Desa Riding terbakar paling luas dengan area terbakar seluas 3052.3 ha di tahun 2015 dan 742.8 ha di tahun 2019. Kebakaran hutan dan lahan gambut yang terjadi pada tahun 2015 dan 2019, sebagian besar terjadi di kelas penutupan lahan non hutan yaitu belukar rawa dan tanah terbuka. Perilaku masyarakat yang utama dapat memicu terjadinya kebakaran lahan gambut di seluruh wilayah studi adalah penanaman padi dengan sistem sonor, penyiapan lahan dengan pembakaran dan kegiatan mencari ikan pada musim kemarau.

Tingkat pengetahuan masyarakat di wilayah studi mengenai kebakaran hutan dan lahan gambut termasuk dalam kategori sedang (56.7\%-80\%). Demikian pula persepsi masyarakat terhadap pengendalian kebakaran hutan dan lahan gambut termasuk dalam kategori sedang (56.7\%-83.3\%). Keikutsertaan masyarakat dalam kegiatan penyuluhan maupun pelatihan dapat meningkatkan pengetahuan, wawasan dan persepsi terhadap kejadian kebakaran hutan dan lahan gambut serta pengendaliannya. Tingkat pengetahuan memiliki korelasi yang signifikan dengan persepsi masyarakat, dengan nilai Sig (2-tailed) $<0.05(0.000-0.01)$ pada seluruh wilayah studi. Koefisien korelasi variabel keduanya menunjukkan hubungan yang searah (0.400-0.809), dimana semakin tinggi pengetahuan yang dimiliki masyarakat maka dapat meningkatkan persepsi masyarakat yang positif terhadap upaya pengendalian kebakaran. Persepsi masyarakat yang positif terhadap upaya pengendalian kebakaran hutan dan lahan gambut, diharapkan dapat meningkatkan partisipasi pada tingkat tapak yang akan menentukan keberhasilan dalam mengendalikan kebakaran hutan dan lahan gambut.

\section{UCAPAN TERIMA KASIH}

Penulis mengucapkan terima kasih kepada Pusat Teknologi Pengembangan Sumber Daya Wilayah, Badan Pengkajian dan Penerapan Teknologi (PTPSW-BPPT) yang telah memfasilitasi penulis utama dalam melakukan penelitian, terutama kepada Hartanto Sanjaya, M.Sc sebagai ketua tim pelaksanaan kegiatan penelitian ini beserta tim dan Kepala Balai Pengendalian Perubahan Iklim dan Kebakaran Hutan dan Lahan Wilayah Sumatera yang telah membantu memfasilitasi kegiatan di lapangan. 


\section{DAFTAR PUSTAKA}

[BBSDLP] Balai Besar Sumberdaya Lahan Pertanian. 2011. Peta Lahan Gambut Indonesia Skala 1:250.000. Bogor (ID): BBSDLP.

[KLHK] Kementerian Lingkungan Hidup dan Kehutanan. 2015. The 2105 Land and Forest Fire In Indonesia: Impacts, Efforts and Expectations. Ministry of Environment and Forestry Republic of Indonesia. Jakarta (ID): Kementerian Lingkungan Hidup dan Kehutanan.

[KLHK] Kementerian Lingkungan Hidup dan Kehutanan. 2016. Peraturan Menteri Lingkungan Hidup dan Kehutanan Nomor P.32/MenLHK/Setjen/Kum.1/3/2016 tentang Pengendalian Kebakaran Hutan. Jakarta (ID): KLHK.

[KLHK] Kementerian Lingkungan Hidup dan Kehutanan. 2019. Rekalkulasi Penutupan Lahan Indonesia Tahun 2018. Jakarta (ID): Kementerian Lingkungan Hidup dan Kehutanan.

[KLHK] Kementerian Lingkungan Hidup dan Kehutanan. 2020. Rekapitulasi Luas Kebakaran Hutan dan Lahan (ha) per Provinsi di Indonesia Tahun 2014-2019 [Internet]. [diunduh 2019 Agustus 20]. Tersedia pada: http://sipongi.menlhk.go.id/pdf/ luas_kebakaran.

Arifin HS, Fuady I, Kuswarno E. 2017. Analisis faktor yang mempengaruhi persepsi mahasiswa untirta terhadap keberadaan perda syariah di kota serang. Jurnal Penelitian Komunikasi dan Opini Publik. 21(1): 88-101.

Chokkalingam U, Suyanto, Permana RP, Kurniawan I, Mannes J, Darmawan A, Khususiyah N, Susanto RH. 2004. Pengelolaan api, perubahan sumberdaya alam dan pengaruhnya terhadap kehidupan masyarakat di areal rawa/gambut-Sumatera bagian selatan. CIFOR Research Paper. 36-46.

Endrawati. 2016. Analisis Data Titik Panas (Hotspot) dan Areal Kebakaran Hutan dan Lahan Tahun 2016. Jakarta (ID): Direktorat Inventarisasi dan Pemantauan Sumber Daya Hutan, Ditjen Planologi Kehutanan dan Tata Lingkungan Kementerian Lingkungan Hidup dan Kehutanan.

Endrawati, Purwanto J, Nugroho S, Sugardiman RA. 2018. Identifikasi areal bekas kebakaran hutan dan lahan menggunakan analisis semi otomatis citra satelit landsat. Di dalam: Windiastuti R, Oktaviani N, Oktaviani M, Suryanegara E, Pujawati I, et al. editor. Prosiding Seminar Nasional Geomatika pada Seminar Nasional Geomatika Tema Inovasi Teknologi Penyediaan Informasi Geospasial Untuk Pembangunan Berkelanjutan [Internet]. [2017 November 14; Bogor, Indonesia]. [diunduh 2020 Agustus 13]. Tersedia pada: https://semnas.big.go.id/index.php/SN/issue/view/4.

Gaveau DLA, Salim MA, Hergoualc'h K, Locatelli B, Sloan S, Wooster M, Marlier ME, Molidena E, Yaen H, DeFries R, et al. 2014. Major atmospheric emissions from peat fires in Southeast Asia during nondrought years: evidence from the 2013 Sumatran fires. Scientific Reports. 4: 1-7. doi: http://doi.org/10.1038/srep06112.

Giglio L, Descloiters J, Justice CO, Kaufman YJ. 2003. An enhanced contextual fire detection algorithm for MODIS. Remote Sensing of Environment. 87(2): 273-282.

Hastuti S, Muin A, Thamrin E. 2014. Keanekaragaman jenis vegetasi pada hutan rawa gambut sekunder dan belukar rawa Desa Sungai Pelang Kabupaten Ketapang. Jurnal Hutan Lestari. 2(3): 435-443.

Hudiyani I, Ninuk P, Pang SA, Hardjanto. 2017. Persepsi petani terhadap hutan rakyat pola agroforestri di Kabupaten Wonogiri Provinsi Jawa Tengah. Jurnal Penyuluhan. 13(1): 64-78.

Larastiti C. 2018. Sonor dan bias cetak sawah di lahan gambut. Jurnal Bhumi. 4(1): 67-87.

Martin E, Winarno B. 2010. Peran para pihak dalam pemanfaatan lahan gambut; studi kasus di Kabupaten Ogan Komering Ilir, Sumatera Selatan. Jurnal Analisis Kebijakan Kehutanan. 7(2): 81-95.

Masganti, Wahyunto, Dariah A, Nurhayati, Yusuf R. 2014. Karakteristik dan potensi pemanfaatan lahan gambut terdegradasi di Provinsi Riau. Jurnal Sumberdaya Lahan. 8: 47-54.

Medrilzam, Dargusch P, Herbohn J, Smith C. 2013. The socio-ecological drivers of forest degradation in part of the tropical peatlands of Central Kalimantan, Indonesia. Forestry. 87: 335-345. doi: 10.1093/forestry/cpt033. 
Murdiyarso D, Lebel L. 2007. Local to global perspectives on forest and land fires in Southeast Asia. Mitigation and Adaptation Strategies for Global Change. 12(1): 3-11. doi: 10.1007/s11027-006-90554.

Nurlia A, Waluyo EA, Martin E. 2018. Efektivitas kebijakan pembukaan lahan tanpa bakar dalam mengurangi kejadian kebakaran di lahan gambut (kasus di Rengas Merah, Kabupaten OKI, Sumatera Selatan). Di dalam: Hesti LT, Lailan S, Mamat R, Edwin M, editor. Prosiding Merawat Asa Restorasi Gambut, Pencegahan Kebakaran dan Peningkatan Kesejahteraan Masyarakat pada Seminar Nasional [Internet]. [2018 Juli 25; Palembang, Indonesia]. [diunduh 2020 Mei 01]. Tersedia pada: https://www.researchgate.net/publication/332555398.

Ratmini NP, Yohanes. 2013. Kajian tanam sistem sonor terhadap varietas unggul padi di lahan pasang surut Sumatera Selatan (Studi Kasus di Daerah Pasang Surut Telang). Jurnal Lahan Suboptimal. 2(1): 75-80. Saharjo BH. 2016. Pengendalian Kebakaran Hutan dan atau Lahan Indonesia. Bogor (ID): IPB Press.

Saharjo BH, Syaufina L, Nurhayati AD, Putra EI, Wardana. 2017. Pemanfaatan Lahan Gambut dan Emisi Gas Rumah Kaca. Bogor (ID): IPB Press.

Sarwono J. 2006. Analisis Data Penelitian Menggunakan SPSS 13. Bandung (ID): Andi.

Sugiarto, Siagian D, Lasmono TS, Deny SO. 2001. Teknik Sampling. Jakarta (ID): Gramedia Pustaka Utama. Sugiyono. 2011. Statistik Non Parametrik untuk Penelitian. Bandung (ID): Alfabeta.

Suratmo FG, Husaeni EA, Jaya NS. 2003. Pengetahuan Dasar Pengendalian Kebakaran Hutan. Bogor (ID): Fakultas Kehutanan IPB.

Syachroni SH, Iskandar S, Deris M. 2019. Kontribusi tanaman sub sektor kehutanan terhadap pendapatan masyarakat di Desa Pematang Kasih Kecamatan Pematang Panggang Kabupaten Ogan Komering Ilir (OKI) Provinsi Sumatera Selatan. Jurnal Sylva. 8(1): 30-37.

Syaufina L. 2008. Kebakaran Hutan dan Lahan di Indonesia: Perilaku Api, Penyebab dan Dampak Kebakaran. Malang (ID): Bayumedia Publishing.

Thoha M. 2003. Kepemimpinan dalam Manajemen: Suatu Pendekatan Perilaku. Jakarta (ID): Raja Grafindo Persada.

Trinirmalaningrum, Dalidjo N, Siahaan FR, Widyanto U, Achsan IA, Primandari T, Wardana KW. 2015. $D i$ Balik Tragedi Asap: Catatan Kebakaran Hutan dan Lahan 2015. Jakarta (ID): Asia Foundation.

Wahyunto, Ritung S, Nugroho K, Sulaiman Y, Hikmarullah, Tafakresnanto C, Suparto Sukarman. 2013. Peta Arahan Lahan Gambut Terdegradasi di Pulau Sumatera Skala 1:250.000. Bogor (ID): Badan Litbang Pertanian, Kementerian Pertanian.

Wahyunto, Ritung S, Subagjo H. 2005. Sebaran Gambut dan Kandungan Karbon Pulau Sumatera/Peat Distributions and Carbon Contents of Sumatera Island (Buku 1). Bogor (ID): Wetlands International Canadian International Development Agency (CIDA).

Watts AC, Kobziar LN. 2012. Smoldering Combustion in Organic Soils: Peat and Muck Fires in the Southeastern U.S. [Internet]. [diunduh 2020 Mei 01]. Tersedia pada: www.southernfireexhchange.org.

World Bank. 2016. Kerugian dari Kebakaran Hutan: Analisa Dampak Ekonomi dari Krisis Kebakaran Hutan Tahun 2015. Jakarta (ID): World Bank. 